\title{
METHODOLOGY OF RENDERING HYBRIDITY IN FICTIONAL TEXTS (BASED ON THE UKRAINIAN TRANSLATIONS OF A. CONAN DOYLE'S STORIES)
}

\section{Povoroznyuk R. V.}

\section{INTRODUCTION}

Analysing the problems of translation, we're invariably drawn to the notion of genre, its cross-cultural peculiarities, similar and contrasting features of the purported generic namesakes in the associated cultures. According to K. Reiß and H.Vermeer, the genres are divided into three principal classes: genres which may be found in all cultures, genres which may be found in more than one, but not in all cultures, and genres which are typical of hardly more than one culture ${ }^{1}$.

In a similar vein, generic conventions vary from culture-specific, i.e. different from culture to culture, and more or less universal, or at least supracultural. But even in the case of supra-cultural or universal conventions, the specific linguistic realization in the individual languages and cultures ${ }^{2}$ may differ. Hence, the hybrid translations of fictional texts replete with terminological units and possessing rhetorical properties of academic literature and fiction evolve.

Based on our study reference data, medicofictional hybrid texts combine the formal and expressive conventions of fiction, and informative and terminological conventions of medical texts. Cultural-textual hybridity ${ }^{3}$ is thus viewed as a result of discourse interference ${ }^{4}$ and the essence of macrostructural texts ${ }^{5}$.

The aim of the present study is to analyze the translation procedures applied for rendering medical terminology outside of a specialized text, and to evaluate the Ukrainian equivalents suggested in the authorized (by M. Dmytrenko) and unauthorized (by S. Ukoz) translations of A. Conan Doyle's stories in terms of their adequacy and acceptability.

${ }^{1}$ Reiß, K. Vermeer, H.J. (1984). Grundlegung einer Allgemeinen Translationstheorie (Linguistische Arbeiten 147). Tübingen: Niemeyer. P. 192.

${ }^{2}$ M. Agar refers to them as languacultures [Agar, 1996]

${ }^{3}$ S. Simon's term [Simon, 2001, p. 217]

${ }^{4}$ Zauberga, I. (2001). Discourse Interference in Translation. In Klaudy K., Sohár A. \& Károly K. (Eds), Across Languages and Cultures, 2 (2), P. 265.

${ }^{5}$ Pym, A. (2014). Exploring Translation Theories. London \& New York: Routledge. P. 195. 
Our research hypothesis posits that the fictional texts with a high ratio of medical terminology require sense-for-sense, rather than word-for-word translation techniques. It promotes the study of etymological features of the corresponding terminology in the original and translated versions of A. Conan Doyle's stories. Further, a descriptive statistical analysis of literal and oblique translation techniques was made to prove our claim.

To corroborate our hypothesis, we used the following methods: descriptive statistical analysis of terminological units from various thematic blocks in order to assess their etymological correspondence to the original units, distributional analysis of the translation techniques and statistical analysis of their frequency, contrastive analysis of the original terms and their equivalents in order to evaluate the translation's adequacy and acceptability. Materials of the study include original and translated texts of "A Study in Scarlet", "The Sign of the Four", "The Hound of the Baskervilles" by A. Conan Doyle (their Ukrainian versions produced by M. Dmytrenko, S. Ukoz, and the Russian one, by N. Volzhyna).

\section{Theoretical background}

Sonja Tirkkonen-Condit places intercultural communication at the root of hybridization, whose processes often reflect those of pidginisation: "While pidginisation in the course of time may result in the emergence of new languages, i.e., creoles, hybridisation may result in the emergence of new domestic text types and genres"6.

Terminological lexis (LSP, language for special purposes) is a cornerstone of most specialized genres and text types, namely in the field of medicine. In this regard, Ieva Zauberga emphasises three major factors reflecting on its translation and, by extension, enhancing the degree of hybridity of target texts: first, the ideological background, i.e. the prestige accorded to the source culture in relation to the target culture; second, translator's competence, i.e., the translator's ability to rationalise translation process and choose an adequate translation strategy; third, the skopos of translation, i.e., hybrid features may be deliberately imposed upon the translation to enable the text to serve a given function ${ }^{7}$.

Unlike Sonja Tirkkonen-Condit (2001), we don't consider medicofictional hybridity a transitory one; rather, as Anthony Pymobserves, such translated texts mark out lines between at last two languages and

${ }^{6}$ Tirkkonen-Condit, S. (2001). EU Project Proposals as Hybrid Texts: Observations URL: a Finnish Research Project. In Klaudy K., Sohár A. \& Károly K. (Eds), Across Languages and Cultures, 2(2), P. 261. DOI 10.1556/Acr.2.2001.2.9

${ }^{7}$ Zauberga, I. (2001). Discourse Interference in Translation. In Klaudy K., Sohár A. \& Károly K. (Eds), Across Languages and Cultures, 2(2), P. 265. 
cultures; they thus posit the separation and possible purity of both; this in turn supports the ideal of pure or natural language use $e^{8}$.

Terminological variation poses a lot of challenges in the process of preliminary translatorial source text (ST) processing, and, further on, target text (TT) creation. First of all, terminological clusters represent various types of terminological variation (e.g. orthographic variation, lexical variation, morphological variation, reduction, permutation, etc.). At the TT generation stage, the translator should be able to predict the reader's response and relay the original information coherently, filling it with lay terms, explanations and descriptive renderings.

Translatorial terminological variation is commonly analysed within userbased (geographic, temporal or social variation) and usage-based (tenor, field, and mode) frameworks ${ }^{9}$. Along with these broad divisions, Freixa names the following subtypes:(1) dialectal, caused by different origins of the authors and translators; (2) functional, caused by different communicative registers; (3) discursive, caused by different stylistic and expressive needs of the authors and translators; (4) interlinguistic, caused by contact between languages; (5) cognitive, caused by different conceptualizations and motiv ations ${ }^{10}$.

In this regard, it is not surprising why Tanja Collet ${ }^{11}$ pointed to a connection existing between a term and overall text coherence. Even in specialised texts, authors sometimes deviate from the traditional view of using only one term consistently throughout the text to refer to a particular concept. From a communicative point of view, "each sender adapts his expression to the specific communication situation" [Cabré, 1995, p. 8]. This explains why in certain communicative contexts a lexical variant is sometimes preferred over a term that appears in a specialised dictionary. Thus, for a translator it is important to know what source and target language terms are commonly used to address a concept in a specific communicative setting.

${ }^{8}$ Pym, A. (2001). Against Praise of Hybridity. In Klaudy K., Sohár A. \& Károly K. (Eds), Across Languages and Cultures, 2(2), 195-206.

${ }^{9}$ Gregory, M. \& Carroll S. (1978). Language and Situation: Language Varieties and Their Social Contexts. London: Routledge and Kegan Paul.

${ }^{10}$ Freixa, J. (2006). Causes of Denominative Variation in Terminology: A Typology Proposal. In Terminology International Journal of Theoretical and Applied Issues in Specialized Communication 12 (1), 51-77. DOI 10.1075/term.12.1.04fre, p. 52.

${ }^{11}$ Collet, T. (2004). What's a Term? An Attempt to Define the Term within the Theoretical Framework of Text Linguistics. Linguistica Antverpiensia (3), 99-111. 


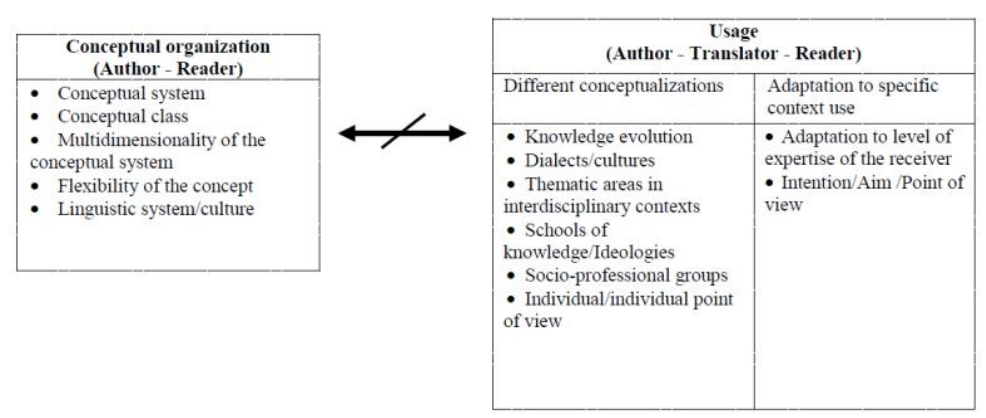

Fig. 1. Factors of terminological variation in SL and TL texts

There are essentially two alternative sets of proposals regarding potential causes of the patterns in question. One set of proposals is based on systemic functional linguistics and situates causes in the social realm, while the other set chooses to situate causes for some of these effects within the cognitive realm ${ }^{12}$. It is through the contrastive data that medicofictional hybridity comes to light and transforms into a 'translation universal' imposed by a specific text type.

M. Kajzer-Wietrzny abides by the view that the range of vocabulary used in translations is narrower, which is indicated by lower lexical density, greater percentage of high frequency words and by the fact that the list head of a corpus of translated texts accounts for a larger area of the corpus ${ }^{13}$. This opinion might also explain the specific type of hybridity existing only on the level of target rather than original medicofictional texts.

However, to the same extent as literary translators are no longer viewed as mere vehicles for knowledge transmission across intertwined networks, interpreters and creators of target medicofictional texts turn into knowledge brokers.

A. Lam's analys is identifies two categories of hybrid creators with different boundary-crossing functions and shows how their particular alignments influence the liminality where knowledge brokering occurs ${ }^{14}$. Thus, the 'artistacademics' whose careers span art and academia concurrently experience

12 Halverson, S. L. (2015). The Status of Contrastive Data in Translation Studies. In Across Languages and Cultures, 16 (2), 163-185. DOI 10.1556/084.2015.16.2.2.

13 Kajzer-Wietrzny, M. (2016). Simplification in Interpreting and Translation. In Across Languages and Cultures, 16 (2), 233-255.

${ }^{14}$ Lam, A. (2017). Boundary-Crossing Careers and the 'Third Space of Hybridity': Career Actors as Knowledge Brokers Between Creative Arts and Academia. In Environment and Planning A: Economy and Space, 50 (8), 1716-1741. DOI 10.1177/0308518X17746406 
recurrent micro-role transitions. They are 'organic' hybrids operating at the 'overlapping space' where knowledge translation and integration occur naturally in everyday work. They are 'embedded' knowledge brokers. The 'artists -inacademia', who cross over from the art world to academia, experience more permanent macro-role transitions. They are 'intentional hybrids' who make conscious efforts to bridge two discrete work domains by creating a separate 'transitional space'. Their knowledge brokering activities are instrumental in transforming both their own knowledge and that of their work context: they are transformative knowledge brokers.

Taking a metaphorical leaf from A. Lam's book, we might extrapolate the same dichotomy on two discrete alignments of medicofictional translators: 'translators-academics' striving towards acceptability and favouring oblique translation, and 'translators-in-academia' opting for adequacy on G. Toury's terms marked with a preponderance of calques, borrowings and direct (rather than oblique) terminologic al equivalents.

The analysis of translated versions of hybrid fictional texts with a high ratio of medical terminology shows that some of them follow quite closely the original text, without making any attempt at linguistic and cultural adaptation, while others transplant the foreign terminological units into the receiving culture. The relatively small number of the latter is explained by a high status of the original texts.

According to G. Toury's classification, the first group is made of adequacy-oriented translations, i.e. focused on the exact reproduction of a source language text's (SLT's or prototext's) features ${ }^{15}$. On the other hand, acceptability-oriented translations seek to meet the requirements of the target culture receiving the metatext (target language text, TLT).

This paradigmatic framework of concepts funnels toward a set of research methodologies. Study of lexical resources and multilingual corpora provides synonym clusters, inflectional and derivational variants, or patterns of pronoun/verb agreement. During the stage of pre-translational analysis, translator's specialized medical knowledge is used for concept mapping, delving into ontological relations and parsing down medical roots and affixes.

Our choice of study material exhibits underlying currents of hybridity: on the one hand, it is well known that Sir Arthur Ignatius Conan Doyle was a British writer and physician (surgeon and ophthalmologist), and his educational and professional background leaves an indelible imprint on all of his works. This is what Albert Neubert calls a formative role any literary text

15 Toury, G. (1995). Descriptive Translation Studies and Beyond. Amsterdam/ Philadelphia: John Benjamins Publishing Co., p. 56. 
plays in the life of different communicative communities ${ }^{16}$. On the other hand, our corpus of Conan Doyle's texts translated into Ukrainian include both authorized and unauthorized (interlinear) samples where hybridity or hybridness, in A. Neubert's terms, is acutely felt. Our research provides grounds for substantiating the status of interlingual terminological variation as a diagnostic by-product of the influences wielded by translations on target discourse ${ }^{17}$.

\section{Results and their discussion}

Our research findings show that the process of rendering terminological variation in medicofictional hybrid texts lies within the domain of G. Toury's principal laws. The law of growing standardisation requires "items... to be selected on a level which is lower than the one where textual relations have been established in the source text" ${ }^{18}$, where "lower" means on a less text-specific level. As a result, "disambiguation and greater simplification" $" 19$ of the ST terminological material is achieved.

On the other hand, a hybrid nature of our sample presupposes a certain interference postulated by G. Toury in the following manner: "In translation, phenomena pertaining to the make-up of the source text tend to be transferred to the target text" ${ }^{\text {20 }}$.

Translation of medical terminology is made possible by a subtle interplay of changes inflicted upon the original unit: in case of the denotative variation it is the form that is most affected (morphological, orthographic changes resulting in ellipses and abbreviations).

Terminological variation may be observed intra-lingually when there is a choice of several nominations usually belonging to different registers (cataract is a marker of formal communication between experts while більмо (back-translated: walleye, eyesore) would be more fitting for the informal lay communication):

${ }^{16}$ Neubert, A. (2001). Some Implications Regarding Translations as Hybrid Texts. In Klaudy K., Sohár A. \& Károly K. (Eds), Across Languages and Cultures, 2(2), p. 181.

${ }^{17}$ Neubert, A. (2001). Some Implications Regarding Translations as Hybrid Texts. In Klaudy K., Sohár A. \& Károly K. (Eds), Across Languages and Cultures, 2 (2), p. 181.

18 Toury, G. (1995). Descriptive Translation Studies and Beyond. Amsterdam/ Philadelphia: John Benjamins Publishing Co. p. 269.

19 Toury, G. (1995). Descriptive Translation Studies and Beyond. Amsterdam/ Philadelphia: John Benjamins Publishing Co. p. 270.

${ }^{20}$ Toury, G. (1995). Descriptive Translation Studies and Beyond. Amsterdam/ Philadelphia: John Benjamins Publishing Co. p. 275. 
card had developed like a cataract $^{21}$. - Ukrainian: наче більма (backtranslated: walleye, eyesore), де-не-де виднілися оголошення ${ }^{22}$.

Inter-lingual variation is a natural response to the phenomenon of interference from the source language text. The transfer of ST's salient features may be negative (when the translation deviates from what is normal in the target-system) or positive (when it does not). For instance, in the original the reference is made to the guaiac paper (made from wood resin of Guaiacum trees), while in translation to Guaiacol (aromatic oil):

guaiacum test ${ }^{23}$. - Ukrainian: спосіб з гваяколом (back-translated: Guaiacol method) $)^{24}$.

Faulty rendering is a sure sign of "false fluency", or negative ST interference. However, even when the results of transfer are invisible to the reader (since positive transfer appears normal in the target system), there is still interference.

On the intra-textual level, terminological variation derives from a deliberate intention of the author to diversify the appellation chain, stumbling against a lack of corresponding synonyms in the target language or reluctance on the part of the translator to profit from the linguistic potential he/she is endowed with. For example, in the original fragment of A Study in Scarlet, there are several synonyms denoting the disease: enteric fever ${ }^{25}$, typhoid fever ${ }^{26}$ and colloquial ellipsoid - typhoid ${ }^{27}$. Meanwhile, the Ukrainian translator uses a uniform equivalent «черевний тиф» (backtranslated: typhoid fever) diminishing the overall expressive effect.

Hybridity is a clear product of the complex, processual and dynamic transcultural relation; furthermore, "hybridity is always subject to discursive

21 Doyle, A. K. (2007). The Complete Stories of Sherlock Holmes. London: Wordsworth Library Collection. P. 7.

22 Doyl', A.K. (2015). Etyud U Yasno-Chervonykh Kol'orakh (Pereklad Ukrayins'koyu M. Dmytrenka). Retrieved September 21, 2018, URL: http://www.zarlit.com/lib/doyle/0v8he.html.

23 Doyle, A.K. (2007). The Complete Stories of Sherlock Holmes. London: Wordsworth Library Collection. P. 16

24 Doyl', A.K. (2015). Etyud U Yasno-Chervonykh Kol'orakh (Pereklad Ukrayins'koyu M. Dmytrenka). Retrieved September 21, 2018, URL: http://www.zarlit.com/lib/doyle/0v8he.html.

25 Doyle, A.K. (2007). The Complete Stories of Sherlock Holmes. London: Wordsworth Library Collection. P. 13.

26 Doyle, A.K. (2007). The Complete Stories of Sherlock Holmes. London: Wordsworth Library Collection. P. 35.

27 Doyle, A.K. (2007). The Complete Stories of Sherlock Holmes. London: Wordsworth Library Collection. P. 36. 
preemption" 28 . As a result, the typical features of the hybrid text are most vividly seen through the prism of the target language. They represent those aspects of translation strategy which Riitta Jääskeläinen defines as "a series of competencies, a set of steps or processes that favor the acquisition, storage, and/or utilization of information" 29 . These instances of decisionmaking would actually reflect a particular strategy the translator is opting for: domestication or alienation, or exoticisation and naturalization with an interposing stage of neutralization ${ }^{30}$.

S. Tirkkonen-Condit's Unique Items Hypothesis (UIH) states that targetlanguage specific elements, which do not have equivalents in the source language, tend to be under-represented in translated texts, since "they do not readily suggest themselves as translation equivalents" 31 .

To prove the crucial role terminological variation plays on the intertextual level, we analysed several versions of The Hound of the Baskervilles in translation - an authorized Ukrainian one by M. Dmytrenko, an unauthorized interlinear Ukrainian translation by S. Ukoz based on the Russian version by N.Volzhyna, which was taken as a reference (results are presented in absolute and percentage values in table 1).

Contrasting tendencies were observed in:

- the ratio of Greek/Latin/native equivalents of the original terms (dyspnoе - діспное (back-translated: dyspnoe) ${ }^{32}$ and ядуха (backtranslated: short breath $)^{33}$ );

- the ratio of archaic/temporally-unmarked terms in translation (cardiac exhaustion - сериева недостатність (back-translated: heart

${ }^{28}$ Kraidy, M. (2002). Hybridity in Cultural Globalization. Communication Theory, 12 (3), 316-339. Retrieved November 1, 2018, URL: https://repository.upenn.edu/cgi/ viewcontent.cgi?article $=1334 \&$ context=asc_papers., p. 14.

${ }^{29}$ Jääskeläinen, R. (1999). T apping the Process: an Explorative Study of the Cognitive and Affective Factors Involved in Translating. Joensuu: University of Joensuu Publications in Humanities.

${ }^{30}$ Jaskanen, S. (1999). On the Inside Track to Loserville, USA: Strategies Used in Translating Humour in T wo Finnish Versions of Reality Bites. Thesis (MA), University of Helsinki. Retrieved October 1, 2018, URL: http://ethesis.helsinki.fi/ julkaisut/hum/engla/pg.

31 Tirkkonen-Condit, S. (2004). "Unique Items: Over- or Under-Represented in Translated Language?” In A. Mauranen \& P. Kujamäki (Eds), Translation Universals: Do They Exist? (pp. 177-184). Amsterdam/Philadelphia: John Benjamins Publishing Co., p. 177-178.

${ }^{32}$ Doyl', A.K. (2011). Sobaka Baskerviliv (Pereklad Ukrayins'koyu M.Dmytrenka). Retrieved October 13, 2018, URL: http://www.ukrcenter.com/Literatura/Artur-KonanDoyl/41192-3/Sobaka-Baskerviliv.

33 Doyl', A.K. (2013). Sobaka Baskerviliv. Retrieved September 24, 2018, URL: http://sergij.ucoz.net/load/khudozhni_tvori/a_konan_dojl_quot_sobaka_baskervilej_quot/3 $-1-0-8$. 
failure) $)^{34}$ and упадок сериевої діяльності (back-translated: heart decline $)^{35}$ )

- the ratio of contextual equivalents of a wider/narrow use (long standing organic disease - застаріла органічна хвороба серия (backtranslated: chronic organic heart disease) ${ }^{36}$ and застарілий органічний порок серия (back-translated: chronic organic heart failure ${ }^{37}$ );

Table 1

\section{Contrastive distributional analysis of terminological variation in the} authorized and unauthorized versions of the Ukrainian translation

\begin{tabular}{|c|c|c|c|c|c|c|c|}
\hline \multicolumn{4}{|c|}{$\begin{array}{l}\text { Authorised Ukrainian translation } \\
\text { (M. Dmytrenko) }\end{array}$} & \multicolumn{4}{|c|}{$\begin{array}{l}\text { Unauthorised interlinear Ukrainian } \\
\text { translation (S. Ukoz based on the } \\
\text { Russian version by N.Volzhyna) }\end{array}$} \\
\hline \multicolumn{2}{|c|}{$\begin{array}{l}\text { Greek/Latin } \\
\text { equivalents }\end{array}$} & \multicolumn{2}{|c|}{$\begin{array}{c}\text { Native } \\
\text { equivalents }\end{array}$} & \multicolumn{2}{|c|}{$\begin{array}{l}\text { Greek/Latin } \\
\text { equivalents }\end{array}$} & \multicolumn{2}{|c|}{ Native equivalents } \\
\hline 17 & $76 \%$ & 5 & $24 \%$ & 8 & $58 \%$ & 6 & $42 \%$ \\
\hline \multicolumn{2}{|c|}{ Archaic terms } & \multicolumn{2}{|c|}{$\begin{array}{c}\text { Temporally- } \\
\text { unmarked terms }\end{array}$} & \multicolumn{2}{|c|}{ Archaic terms } & \multicolumn{2}{|c|}{$\begin{array}{c}\text { Temporally- } \\
\text { unmarked terms }\end{array}$} \\
\hline 4 & $23 \%$ & 16 & $77 \%$ & 5 & $41 \%$ & 9 & $59 \%$ \\
\hline \multicolumn{2}{|c|}{$\begin{array}{l}\text { Contextual } \\
\text { equivalents of } \\
\text { wider use }\end{array}$} & \multicolumn{2}{|c|}{$\begin{array}{l}\text { Contextual } \\
\text { equivalents of } \\
\text { narrow use }\end{array}$} & \multicolumn{2}{|c|}{$\begin{array}{l}\text { Contextual } \\
\text { equivalents of } \\
\text { wider use }\end{array}$} & \multicolumn{2}{|c|}{$\begin{array}{l}\text { Contextual } \\
\text { equivalents of } \\
\text { narrow use }\end{array}$} \\
\hline 20 & $89 \%$ & 2 & $11 \%$ & 13 & $94 \%$ & 1 & $6 \%$ \\
\hline \multicolumn{2}{|c|}{$\begin{array}{c}\text { Generalized } \\
\text { correspondences }\end{array}$} & \multicolumn{2}{|c|}{$\begin{array}{c}\text { Specified } \\
\text { correspondences }\end{array}$} & \multicolumn{2}{|c|}{$\begin{array}{c}\text { Generalized } \\
\text { correspondences }\end{array}$} & \multicolumn{2}{|c|}{$\begin{array}{c}\text { Specified } \\
\text { correspondences }\end{array}$} \\
\hline 18 & $81 \%$ & 4 & $19 \%$ & 12 & $91 \%$ & 2 & $9 \%$ \\
\hline \multicolumn{2}{|c|}{$\begin{array}{c}\text { Total number of } \\
\text { instances }(n)\end{array}$} & \multicolumn{2}{|c|}{$\begin{array}{c}\text { Total percentage } \\
(\%)\end{array}$} & \multicolumn{2}{|c|}{$\begin{array}{c}\text { Total number of } \\
\text { instances }(n)\end{array}$} & \multicolumn{2}{|c|}{$\begin{array}{c}\text { Total percentage } \\
(\%)\end{array}$} \\
\hline & & & $\overline{00}$ & & & & 100 \\
\hline
\end{tabular}

34 Doyl', A.K. (2015). Etyud U Yasno-Chervonykh Kol'orakh (Pereklad Ukrayins'koyu M.Dmytrenka). Retrieved September 21, 2018, URL: http://www.zarlit.com/lib/doyle/0v8he.html.

${ }^{35}$ Doyl', A.K. (2013). Sobaka Baskerviliv. Retrieved September 24, 2018, URL: http://sergij.ucoz.net/load/khudozhni_tvori/a_konan_dojl_quot_sobaka_baskervilej_quot/3 $-1-0-8$.

${ }^{36}$ Doyl', A.K. (2011). Sobaka Baskerviliv (Pereklad Ukrayins'koyu M.Dmytrenka). Retrieved October 13, 2018, URL: http://www.ukrcenter.com/Literatura/Artur-KonanDoyl/41192-3/Sobaka-Baskerviliv.

${ }^{37}$ Doyl', A.K. (2011). Sobaka Baskerviliv (Pereklad Ukrayins'koyu M.Dmytrenka). Retrieved October 13, 2018, URL: http://www.ukrcenter.com/Literatura/Artur-KonanDoy1/41192-3/Sobaka-Baskerviliv. 
- the ratio of generalized/specified terminological correspondences (maxillary curve - щелепний вигин (back-translated: jaw curve) [Doyl', 2013] and будова щелепи (back-translated: jaw composition) ${ }^{38}$ ).

The primary conceptual mission of translated medicofictional texts is to ensure travel of medical ideas and practices across the culture-specific and knowledge disparate recipient contexts. In this regard, they are typical 'value-infused texts' which, in S. Ciuk, P. James's paradigm ${ }^{39}$, require appropriate and productive accommodations between local and extra-local pressures.

Terminological variation is an imminent factor of rendering hybrid texts, promoting a more successful intercultural understanding. Most often, terminological variation results from explicitation, which, according to Shoshana Blum-Kulka, "is a universal strategy inherent in the process of language mediation"40. In Kinga Klaudy's classification, terminological variation signals either an optional explicitation, resulting from "differences in text-building strategies $<\ldots>$ and stylistic preferences between languages", or pragmatic explicitation due to differences in cultural and/or world knowledge that members of the source and target language community share" ${ }^{41}$. In both cases, a translator needs to add linguistic material in order to explain a terminological concept specific to the source biomedical culture.

Terminological variation is a by-product of deliberate translatorial choices, i.e. translation strategy. Translatorial mistakes originate from an ST's excessive imitation, or faulty medical knowledge (lack of health literacy). On the other hand, medicofictional hybrid texts prove to be a testing ground for translation universals, i.e. simplification, producing texts with a lower lexical density and a lower type-token ratio $^{42}$, normalization/conservatism, "a tendency to exaggerate features of the target

38 Doyl', A.K. (2015). Etyud U Yasno-Chervonykh Kol'orakh (Pereklad Ukrayins'koyu M.Dmytrenka). Retrieved September 21, 2018, URL: http://www.zarlit.com/lib/doyle/0v8he.html.

${ }^{39}$ Ciuk S., James P. (2014). Interlingual Translation and the Transfer of Value-Infused Practices: An In-Depth Qualitative Exploration. In Management Learning, 46 (5), 565-581. DOI 10.1177/1350507614560304

${ }^{40}$ Blum-Kulka, S. (1986). "Shifts of Cohesion and Coherence in Translation." In J. House \& S. Blum-Kulka (Eds), Interlingual and Intercultural Communication (pp. $17-$ 35). Tübingen: Narr. DOI 10.1075/btl.48.04che, p. 21

${ }^{41}$ Kraidy, M. (2002). Hybridity in Cultural Globalization. Communication Theory, 12 (3), 316-339. Retrieved November 1, 2018, URL: https://repository.upenn.edu/cgi/ viewcontent.cgi?article $=1334 \&$ context $=$ asc_papers., p. 106

${ }^{42}$ Baker, M. (1996). "Corpus-Based Translation Studies: The Challenges that Lie Ahead." In H. Somers (Ed.), Terminology, LSP and Translation. Studies in Language Engineering in Honour of Juan C. Sager (pp. 175-186). Amsterdam/Philadelphia: John Benjamins Publishing Co. DOI 10.1075/btl.18.17bak, p. 183. 
language and to conform to its typical patterns",43, and levelling out, "the tendency of translated text to gravitate towards the centre of a continuum" 44 . Because of the latter, individual texts in an English translation corpus are more like each other in lexical density and terminological variation ratio than the individual texts in a comparable corpus of original English.

However, looking at hybridity from an anthropological perspective, we might disregard the previous emphasis on instrumentality and outcome and look at medicofictional translation as at a serious human endeavor, a feature of human life-in-movement, a meaningful and meaning-making process ${ }^{45}$.

As G. Delanty rightfully suggests ${ }^{46}$, in the field of conceptual and cultural translation three pivotal problems are addressed (all of them relevant to medifiction as translation object): universalist versus contextualist positions, Eurocentrism, and the problemof conceptual and cultural translations between western and non-western thought. To these might be added disparities of biomedical knowledge and dis similar operations of national biomedical cultures, requiring hybridity (assimilation) in translation.

Translational procedures rely heavily on what Anthony Pym calls directional equivalence, an asymmetric relation where the creation of an equivalent by translating one way does not imply that the same equivalence will also be created when translating the other way ${ }^{47}$. In cases of directional equivalence $^{48}$, the translator has a choice between several translation strategies, and those strategies are not dictated by the source text. So, we may conclude that equivalence is always assumed, and moreover occurs on any level, from form to function.

The strategies for directional equivalence are reduced into two opposing poles; one adhering to SL norms and the other to TL norms. The same

${ }^{43}$ Baker, M. (1996). "Corpus-Based Translation Studies: The Challenges that Lie Ahead." In H. Somers (Ed.), Terminology, LSP and Translation. Studies in Language Engineering in Honour of Juan C. Sager (pp. 175-186). Amsterdam/Philadelphia: John Benjamins Publishing Co. DOI 10.1075/btl.18.17bak, p. 183.

${ }^{44}$ Baker, M. (1996). "Corpus-Based Translation Studies: The Challenges that Lie Ahead." In H. Somers (Ed.), Terminology, LSP and Translation. Studies in Language Engineering in Honour of Juan C. Sager (pp. 175-186). Amsterdam/Philadelphia: John Benjamins Publishing Co. DOI 10.1075/btl.18.17bak, p. 184

${ }^{45}$ Towner, P. H. (2018). Translation from the Other Side: Process before Product or "In Defense of Lost Causes". In The Bible Translator, 69 (2), 150-165. DOI $10.1177 / 2051677018785420$

46 Delanty, G. (2014). Not All Is Lost in Translation: World Varieties of Cosmopolitanism. In Cultural Sociology 8 (4), 374-391. DOI 10.1177/1749975514532261.

${ }^{47}$ Pym, A. (2014). Exploring Translation Theories. 2nd Edition. London \& New York: Routledge, p. 26.

${ }^{48}$ A concept suggested by Anthony Pym [Pym, 2014, p. 26]. 
polarity is observed when analyzing the process of translation in view of its end-result, a text. It concerns such categories as illusionist vs. anti-illusionist translation by Jiř́ Levý ${ }^{49}$. The former "require[s] a work of literature to "look like the original, like reality", much like illusionist theatre ${ }^{50}$. The latter, on the other hand, "boldly play[s] on the fact that [it is] offering the audience a mere imitation of reality" 1 . An illusionist translation theory is based on a contract between translator and reader-the translator will "hide behind the original, as though they were presenting it to the reader directly rather than as intermediaries", and reader in turn will be "prepared to believe' that they are reading the original ${ }^{52}$.

In a similar vein, Juliane House favors the idea of pragmatic (or functional) equivalence over the traditional semantic one. It is quite logical then that in her classification the categories of covert translation vs. overt translation $^{53}$ raise questions related to how readers perceive the TT's sense. Overt translation is the production of a target language text which signals (in a variety of possible ways) that it is a translation. Covert translation, by contrast, produces a target language text which reads like an original text of the given text type in the target language and thus does not signal that it is a translation. The character of translation (overt or covert) is determined as early as at the pre-production ST analysis stage. As every text is shaped by a particular situation, the underlying conditions have to be correctly identified and taken into account by the translator. The scholar goes on to opin e that "a translation text should not only match its source text in function, but employ equivalent situational-dimensional means to achieve that function" ${ }^{\text {" }} 4$. The quality criterion, then, is an extent to which TT mirrors the situation (co-text, context) of ST production. If the ST and the TT differ substantially on situational features, they are not functionally equivalent, and the translation is not of a high quality. To take the edge off this clearly prescriptive point of view, it's worthy of mentioning that Juliane House considers ST essential characteristics to be a cornerstone of translation act's successful or unsuccessful outcome.

The notion of tertium comparationis is of a primary value as far as paratranslation is concerned. For some scholars, it is a piece of reality or thought (a referent, a function, a message) that stands outside all languages.

${ }^{49}$ Levý, J. (2012). Umění Překladu. Prague: Apostrof.

${ }^{50}$ Levý, J. (2012). Umění Překladu. Prague: Apostrof. p. 19.

${ }^{51}$ Levý, J. (2012). Umění Překladu. Prague: Apostrof. p. 20.

${ }^{52}$ Levý, J. (2012). Umění Překladu. Prague: Apostrof.

${ }^{53}$ House, J. (2014). Translation Quality Assessment: Past and Present. London \& New York: Routledge.

${ }^{54}$ House, J. (2014). Translation Quality Assessment: Past and Present. London \& New York: Routledge., p. 49 
Thus, Danica Seleskovitch recommends "listening to the sense," or "deverbalizing" the source text so that one is only aware of the sense, which can be expressed in all languages (théorie $d u$ sens) ${ }^{55}$. The translator then goes from the source text to a third element of comparison (a referent, a function, a message), then from the thing to the corresponding target text.

Translation is thus viewed not only as a linguistic exercise; translators are intervening upon the text, actively changing it as a result of their actions. It is not surprising, then, that Carol Maier refers to translators as "intervenient beings' who may become personally involved in the process of translation or interpretation, either as a result of interaction with the text or, more poignantly, when they are caught in the cross-fire of $\operatorname{war}^{56}$. Translatorial intervention is closely associated with risk-taking and gatekeeping, where translation is a channel through which information reaches audiences in different linguistic communities. The selection of a particular message for translation and the transformation of the message in particular ways are carried out at the gate sections of the translation channel.

\section{CONCLUSIONS}

In the history of translation studies, such notions as accuracy, correctness, or well-formedness have played their important roles in assessing the quality of a translation. Depending on what was understood by translation, those notions had been given different significance.

In terms of translation practice, it means that there is no uniform methodology applicable to each and every text which is especially relevant when the intellectual hybrid fiction is concerned. Thus, what the translation scholars are assessing is the overall effect of the translated version, whether it is understandable for the target audience and whether the special terminology (in our case, medical) is reproduced correctly and consistently within the body of the target text.

Our study's results point out the general tendency towards an acceptability-oriented translation, manifested in the etymology of the target lexemes, use of footnotes and distribution of translation techniques.

While analyzing the distribution of particular translation techniques, we've found out that the translators more readily resorted to calques than borrowings and transcriptions, presumably wishing to make the target version more recognizable for the readers on the phonemic and graphemic levels, a sure signal of an acceptability-oriented strategy.

55 Seleskovitch, D. (2015). L'interprète Dans Les Conférences Internationales: Problèmes De Langage Et De Communication. Paris: Lettres Modernes Minard.

${ }^{56}$ Maier, C. (2007). The Translator as an Intervenient Being. In J. Munday (ed.), Translation as Intervention (Continuum Studies in Translation), 1-18. 
The translators' preference of amplification and oblique translation manifested their intentions to facilitate the overall understanding of the target version on the part of the target audience whose extent of the background knowledge cannot be ascertained. The translators have discriminately administered a wide array of translation transformations relying on a specific type of competence where the referential component predominates.

Although our results cannot be extrapolated to all the fictional texts due to a limited corpus, they shed some light on the applicable translation methodology and factors influencing the translator's decision-making. However, further studies of translation strategies applicable for the terminology in medicofictional texts are required, with a particular focus on hybridity and evaluation parameters of the translation's quality.

\section{SUMMARY}

This study dwells on the methodological issues of rendering hybridity in fictional texts. The aim of the present study is to analyze the translation procedures applied for rendering medical terminology outside of a specialized text, and to evaluate the Ukrainian equivalents suggested in the authorized (by M. Dmytrenko) and unauthorized (by S. Ukoz) translations of A. Conan Doyle's stories in terms of their adequacy and acceptability. To achieve this aim, the following methods were used: descriptive statistical analysis of terminological units, distributional analysis of the translation techniques and statistical analysis of their frequency, contrastive analys is of the original terms and their equivalents in order to evaluate the translation's adequacy and acceptability. Materials of the study include original and translated texts of "A Study in Scarlet", "The Sign of the Four", "The Hound of the Baskervilles" by A. Conan Doyle (their Ukrainian versions produced by M. Dmytrenko, S. Ukoz, and the Russian one, by N. Volzhyna).

The findings prove that some of the translated versions of medicofictional texts follow quite closely the original text, while others transplant the foreign terminological units into the receiving culture; terminological variation promotes hybridity as a textual strategy of explicitation and a broader conceptual strategy of bridging the gap of disparate biomedical cultures.

\section{REFERENCES}

1. Agar, M. (1996). Language Shock: Understanding the culture of conversation. NY : HarperCollins.

2. Baker, M. (1996). "Corpus-Based Translation Studies: The Challenges that Lie Ahead." In H. Somers (Ed.), Terminology, LSP and Translation. Studies in Language Engineering in Honour of Juan C. Sager 
(pp. 175-186). Amsterdam/Philadelphia: John Benjamins Publishing Co. DOI $10.1075 / \mathrm{btl} .18 .17 \mathrm{bak}$

3. Blum-Kulka, S. (1986). "Shifts of Cohesion and Coherence in Translation." In J. House \& S. Blum-Kulka (Eds), Interlingual and Intercultural Communication (pp. 17-35). Tübingen: Narr. DOI 10.1075/btl.48.04che

4. Cabré, M.T. (1995). On Diversity and Terminology. In Terminology International Journal of Theoretical and Applied Issues in Specialized Communication. 2(1), 1-16.

5. Ciuk S., James P. (2014). Interlingual Translation and the Transfer of Value-Infused Practices: An In-Depth Qualitative Exploration. In Management Learning , 46 (5), 565-581. DOI 10.1177/1350507614560304

6. Collet, T. (2004). What's a Term? An Attempt to Define the Term within the Theoretical Framework of Text Linguistics. Linguistica Antverpiensia (3), 99-111.

7. Delanty, G. (2014). Not All Is Lost in Translation: World Varieties of Cosmopolitanism. In Cultural Sociology 8 (4), 374-391. DOI $10.1177 / 1749975514532261$

8. Doyle, A.K. (2007). The Complete Stories of Sherlock Holmes. London: Words worth Library Collection.

9. Doyl', A.K. (2015). Etyud U Yasno-Chervonykh Kol'orakh (Pereklad Ukrayins'koyu M. Dmytrenka). Retrieved September 21, 2018, URL: http://www.zarlit.com/lib/doyle/0v8he.html.

10. Doyl', A.K. (2011). Sobaka Baskerviliv (Pereklad Ukrayins'koyu M. Dmytrenka). Retrieved October 13, 2018, URL: http://www.ukrcenter.com/Literatura/Artur-Konan-Doyl/41192-3/SobakaBaskerviliv.

11. Doyl', A.K. (2013). Sobaka Baskerviliv. Retrieved September 24, 2018, URL: http://sergij.ucoz.net/load/khudozhni_tvori/a_konan_ dojl_quot_sobaka_baskervilej_quot/3-1-0-8.

12. Freixa, J. (2006). Causes of Denominative Variation in Terminology: A Typology Proposal. In Terminology International Journal of Theoretical and Applied Issues in Specialized Communication 12 (1), 51-77. DOI 10.1075/term. 12.1.04fre

13. Gregory, M. \& Carroll S. (1978). Language and Situation: Language Varieties and Their Social Contexts. London: Routledge and Kegan Paul.

14. Halverson, S. L. (2015). The Status of Contrastive Data in Translation Studies. In Across Languages and Cultures, 16 (2), 163-185. DOI 10.1556/084.2015.16.2.2.

15. House, J. (2014). Translation Quality Assessment: Past and Present. London \& New York: Routledge. 
16. Jääskeläinen, R. (1999). Tapping the Process: an Explorative Study of the Cognitive and Affective Factors Involved in Translating. Joensuu: University of Joensuu Publications in Humanities.

17. Jaskanen, S. (1999). On the Inside Track to Loserville, USA: Strategies Used in Translating Humour in Two Finnish Versions of Reality Bites. Thesis (MA), University of Helsinki. Retrieved October 1, 2018, URL: http://ethesis.helsinki.fi/julkaisut/hum/engla/pg.

18. Kajzer-Wietrzny, M. (2016). Simplification in Interpreting and Translation. In Across Languages and Cultures, 16 (2), 233-255.

19. Klaudy, K. (2008). Explicitation. In M. Baker \& G. Saldanha (Eds), Routledge Encyclopedia of Translation Studies (p. 80-85). London: Routledge.

20. Kraidy, M. (2002). Hybridity in Cultural Globalization. Communication Theory, 12 (3), 316-339. Retrieved November 1, 2018, URL: https://repository.upenn.edu/cgi/viewcontent.cgi?article $=1334 \&$ context=asc_papers.

21. Lam, A. (2017). Boundary-Crossing Careers and the 'Third Space of Hybridity': Career Actors as Knowledge Brokers Between Creative Arts and Academia. In Environment and Planning A: Economy and Space, 50 (8), 1716-1741. DOI 10.1177/0308518X17746406

22. Levý, J. (2012). Umění Překladu. Prague: Apostrof.

23. Maier, C. (2007). The Translator as an Intervenient Being. In J. Munday (ed.), Translation as Intervention (Continuum Studies in Translation), 1-18.

24. Neubert, A. (2001). Some Implications Regarding Translations as Hybrid Texts. In Klaudy K., Sohár A. \& Károly K. (Eds), Across Languages and Cultures, 2 (2), 181-193.

25. Pym, A. (2001). Against Praise of Hybridity. In Klaudy K., Sohár A. \& Károly K. (Eds), Across Languages and Cultures, 2 (2), 195-206.

26. Pym, A. (2014). Exploring Translation Theories. London \& New York: Routledge.

27. Reiß, K. \& Vermeer, H.J. (1984). Grundlegung einer Allgemeinen Translations theorie (Linguistische Arbeiten 147). Tübingen: Niemeyer.

28. Seleskovitch, D. (2015). L'interprète Dans Les Conférences Internationales: Problèmes De Langage Et De Communication. Paris: Lettres Modernes Minard.

29. Simon, S. (2001). Cultural - Textual Hybridity. In Klaudy K., Sohár A. \& Károly K. (Eds), Across Languages and Cultures, 2 (2), 217-226.

30. Tirkkonen-Condit, S. (2001). EU Project Proposals as Hybrid Texts: Observations URL: a Finnish Research Project. In Klaudy K., Sohár A. \& Károly K. (Eds), Across Languages and Cultures, 2 (2), 261-264. DOI 10.1556/Acr.2.2001.2.9 
31. Tirkkonen-Condit, S. (2004). "Unique Items: Over- or UnderRepresented in Translated Language?" In A. Mauranen \& P. Kujamäki (Eds), Translation Universals: Do They Exist? (pp. 177-184). Amsterdam/Philadelphia: John Benjamins Publishing Co.

32. Toury, G. (1995). Descriptive Translation Studies and Beyond. Amsterdam/Philadelphia: John Benjamins Publishing Co.

33. Towner, P.H. (2018). Translation from the Other Side: Process before Product or "In Defense of Lost Causes". In The Bible Translator, 69 (2), 150-165. DOI 10.1177/2051677018785420

34. Zauberga, I. (2001). Discourse Interference in Translation. In Klaudy K., Sohár A. \& Károly K. (Eds), Across Languages and Cultures, 2 (2), 265-276.

\section{Information about the author:} Povoroznyuk R. V., PhD, Dr. habil., Assistant Professor, Institute of Philology of Taras Shevchenko National University of Kyiv 60, Volodymyrska str., Kyiv, 01033, Ukraine 